OPEN ACCESS

Edited by:

Johan Van Der Vlag,

Radboud University Nijmegen,

Netherlands

Reviewed by:

Elmar Pieterse,

Radboud University Nijmegen

Medical Centre, Netherlands

Jurgen Dieker,

Nijmegen Center for Molecular Life

Sciences, Netherlands

Ger J. M. Pruijn,

Radboud University Nijmegen,

Netherlands

Elisa Corsiero,

Queen Mary University of London,

UK

*Correspondence:

Marko Radic

mradic@uthsc.edu

tPresent address:

Nishant Dwivedi,

Brigham and Women's Hospital, Harvard Medical School, Boston,

MA, USA

Specialty section:

This article was submitted to

Molecular Innate Immunity,

a section of the journal

Frontiers in Immunology

Received: 27 September 2016 Accepted: 14 March 2017

Published: 30 March 2017

Citation:

Dwivedi N, Hedberg A, Zheng YY, Neeli I, Satoh M, Morel L, Rekvig OP and Radic M (2017) B Cell Tolerance to Deiminated Histones in $B A L B / C$, C57BL/6, and Autoimmune-Prone Mouse Strains.

Front. Immunol. 8:362. doi: 10.3389/fimmu.2017.00362

\section{B Cell Tolerance to Deiminated Histones in BALB/c, C57BL/6, and Autoimmune-Prone Mouse Strains}

\author{
Nishant Dwivedi't, Annica Hedberg', Ying Yi Zheng ${ }^{3}$, Indira Neeli', Minoru Satoh ${ }^{4}$, \\ Laurence Morel ${ }^{3}$, Ole Petter Rekvig² and Marko Radic ${ }^{1 *}$
}

\begin{abstract}
${ }^{1}$ Department of Microbiology, Immunology and Biochemistry, University of Tennessee Health Science Center, Memphis, TN, USA, ${ }^{2}$ Medical Faculty, Department of RNA and Molecular Pathology, Institute of Medical Biology, University of Tromsø, Tromsø, Norway, ${ }^{3}$ Department of Medicine, University of Florida, Gainesville, FL, USA, ${ }^{4}$ Department of Clinical Nursing, University of Occupational and Environmental Health, Fukuoka, Japan
\end{abstract}

Deimination, a posttranslational modification of arginine to citrulline carried out by peptidylarginine deiminases, may compromise tolerance of self-antigens. Patients with connective tissue autoimmunity, particularly rheumatoid arthritis (RA), systemic lupus erythematosus (SLE), or Felty's syndrome, present with autoantibodies to deiminated histones $(\mathrm{dH})$, which thus form a category of antibodies to citrullinated protein antigens (ACPA). In general, ACPA are a sensitive diagnostic for RA and may form in response to the release of nuclear chromatin (DNA plus $\mathrm{dH}$ ) from granulocytes, usually referred to as neutrophil extracellular traps. The aim of this study was to examine spontaneously autoimmune mice for autoantibodies and $T$ cell responses to $\mathrm{dH}$. We compared IgG binding to deiminated and non-deiminated histones $(\mathrm{nH})$ by ELISA and Western blotting in spontaneously autoimmune strains of $(\mathrm{NZB} \times \mathrm{NZW}) \mathrm{F}_{1}$ and NZM2410 together with their derivative congenic strains, C57BL/6.Sle1 and C57BL/6.Sle1.Sle3, which display profound autoreactivity against nuclear self-antigens. The splenocyte proliferation against the two antigens was determined in the spontaneously autoimmune $(N Z B \times N Z W) F_{1}$ strain from which other autoimmune strains used in the study were derived. Immunizations with $\mathrm{dH}$ and $\mathrm{nH}$ were attempted in BALB/c mice to assess their splenocyte response. Splenocytes from BALB/c mice and from autoimmune mice at the time of conversion to autoimmunity proliferated strongly in response to $\mathrm{dH}$, yet serum $\mathrm{lgG}$ from autoimmune $(\mathrm{NZB} \times \mathrm{NZW}) \mathrm{F}_{1}, \mathrm{NZM} 2410$, and C57BL/6.Sle1.Sle3 mice displayed a remarkable bias against binding to $\mathrm{dH}$. At the time of seroconversion, the antibodies already exhibited preference for $\mathrm{nH}$, and only $\mathrm{nH}$ were recovered from circulating immune complexes. Analysis of histone deimination showed constitutive deimination in thymic extracts from C57BL/6 and C57BL/6.Sle1.Sle2.Sle3 triply congenic mice and in spleens of autoimmune triply congenic mice. Our study demonstrates that tolerance mechanisms against $\mathrm{dH}$ are intact in BALB/c and C57BL/6 mice and continue to be effective in mice with overt autoimmunity to $\mathrm{nH}$. We conclude that, in contrast to human RA and SLE patients, where we frequently observe autoantibodies against $\mathrm{dH}$, autoimmune mice maintain strong tolerance mechanisms to prevent the development of autoantibodies to $\mathrm{dH}$.

Keywords: autoimmunity, antibodies to citrullinated protein antigens, citrullines, B cells, lupus erythematosus, rheumatoid arthritis, autophagy, tolerance 


\section{INTRODUCTION}

Antibodies to citrullinated protein antigens (ACPA) are diagnostic markers for rheumatoid arthritis (RA) (1) and also arise in other human autoimmune disorders such as systemic lupus erythematosus (SLE) and Felty's syndrome $(2,3)$. Citrullines are introduced into proteins by peptidylarginine deiminase (PAD) family of enzymes (4), and much effort has been devoted to learning the circumstances that activate PADs and lead to the PADmediated conversion of arginine residues into citrulline residues $(5,6)$. Several citrullinated antigens have been identified in RA, and a common mechanism has been proposed to account for the generation of citrullinated autoantigens (7-9). The proposed mechanism places particular importance on PAD2 and PAD4, enzymes that are expressed in cells of the innate and adaptive immune system $(10,11)$. These calcium-dependent enzymes are activated under inflammatory conditions (5). Direct stimuli of PADs include microbial pathogens and pro-inflammatory chemokines and cytokines (5). The enzymes are also activated by sterile inflammatory stimuli, such as cholesterol and urate crystals (8). In fact, it has been argued that any perforation to the plasma membrane could lead to the activation of PADs (12).

One particularly relevant event that is linked to PAD activation and may contribute to the induction of ACPA is a form of granulocyte cell death, which is induced by microbes and inflammatory stimuli and results in the release of nuclear chromatin $(5,13)$. Such neutrophil extracellular traps (NETs) are considered an innate antimicrobial response because the externalized chromatin is associated with neutrophil granule components such as myeloperoxidase and elastase, which, together with histones themselves, assist in bacterial killing and microbial entrapment (14). In the process of NET release, termed NETosis, PADs gain access to multiple intracellular and extracellular substrates such as histones, filaggrin, fibrinogen, and collagen, which are frequently targeted by ACPA (15). So, it is a prevalent hypothesis that NETosis provides conditions that lead to the production of deiminated (citrullinated) autoantigens that may stimulate cells of the adaptive immune system in the context of an inflammatory response. Moreover, the structural components of NETs, DNA, and histones, also become externalized during NETosis and, in an infection, may become entangled with bacteria and activate the immune system. Interestingly, dendritic cells respond to NETs with the production of interferons and other pro-inflammatory cytokines $(16,17)$. Other forms of cell death may also have consequences for the induction of autoantibodies, as autoantibodies bind to acetylated histones, a modification of apoptotic chromatin that may elicit autoantibody responses in mice and humans $(18,19)$.

To provide a mouse model for the study of ACPA, we sought to identify spontaneous mouse models of systemic autoimmunity that would produce autoantibodies to citrullinated histones. Although PAD4 expression parallels the severity of the inflammatory process in mouse models of RA (20), PAD4's contribution to the production of ACPA has been more difficult to ascertain $(21,22)$. Because ACPA are difficult to induce in most strains of mice (23), questions have been raised whether mouse ACPA participate in RA pathogenesis at all (22). Human ACPA often react with deiminated histones $(\mathrm{dH})$, and antibody binding to citrullinated histone peptides is a sensitive diagnostic test for RA $(2,24)$. Because histones are the major substrates of PADs in neutrophils, and $\mathrm{dH}$ are built into NETs, we expected that spontaneous anti-histone autoantibodies would preferentially bind to PAD-modified histones. However, we observed that mouse autoantibodies from $(\mathrm{NZB} \times \mathrm{NZW}) \mathrm{F}_{1}(\mathrm{NZB} / \mathrm{W})$ mice and their recombinant derivative strains, including NZM2410 and C57BL/6J.Sle1 (B6.Sle1) or C57BL/6J.Sle1.Sle3 (B6.Sle1. Sle3) congenics, showed strong preference for non-deiminated histones $(\mathrm{nH})$ over $\mathrm{dH}$ by ELISA and Western blot. Thus, even after tolerance to histones was broken and autoantibodies to $\mathrm{nH}$ were expressed, autoimmune-prone congenic strains retained $\mathrm{B}$ cell tolerance toward $\mathrm{dH}$. B cell binding to $\mathrm{dH}$ was repressed, whereas autoantibody binding focused instead on PAD4 substrate arginines. The $\mathrm{B}$ cell bias against $\mathrm{dH}$ argues that $\mathrm{dH}$ remain effective tolerogens in autoimmune mice. In support of this possibility, we observed elevated levels of $\mathrm{dH}$ in thymus extracts from B6 and B6.Sle1.Sle2.Sle3 (B6.TC mice) and spleens of autoimmune B6.TC mice. Our observations suggest that, even in overtly autoimmune lupus mice, central (thymic) tolerance inhibits B cells that react with a deiminated variant of an important nuclear autoantigen. These results point to unexpected intricacies in the murine immune response to deiminated autoantigens. We interpret these results as possible outcomes of PAD expression in antigen-presenting cells.

\section{MATERIALS AND METHODS}

\section{Mice}

Sera were obtained from $\mathrm{B} 6$ mice, as well as from NZB/W, NZM2410, B6.Sle1, and B6.Sle1.Sle3 mice at 6-8 months of age. Tissues were prepared from groups of matched B6 and B6.TC mice of 4-6 months of age. Splenocytes were isolated from $6 \mathrm{BALB} / \mathrm{c}$ mice of 4 months of age and $13 \mathrm{NZB} / \mathrm{W}$ F1 female mice that were divided into 3 age groups: 6-10 weeks of age, 20-21 weeks of age, and 25-30 weeks of age. The treatment and care of animals were in accordance with the guidelines of the Office of Research, UTHSC, the University of Florida and the Norwegian Ethical and Welfare Board, and the study overall was approved by UTHSC Institutional Animal Care and Use Committee under the protocol \#11-164.

\section{ELISA}

For binding assays, we treated purified calf-thymus histones with recombinant PAD4 in vitro, as described previously $(2,3)$. To assess the extent of deimination, we analyzed the progress of the reaction by colorimetry of citrullines and testing the resulting $\mathrm{dH}$ by Western blot with an antibody to citrullinated histone H3 (Abcam, ab\#5103). The results of this analysis are shown in Figure 1.

Flat bottom, 96 well microtiter plates (Immulon 4HBX; Thermo Electron Corp.) were coated overnight with $5 \mu \mathrm{g} / \mathrm{ml}$ of $\mathrm{nH}$, poly L-lusine, bovine serum albumin (BSA) (Sigma), ovalbumin (OVA) (Sigma), protamine sulfate (Sigma), or $\mathrm{dH}$, as previously described (25). Plates were washed three times with 


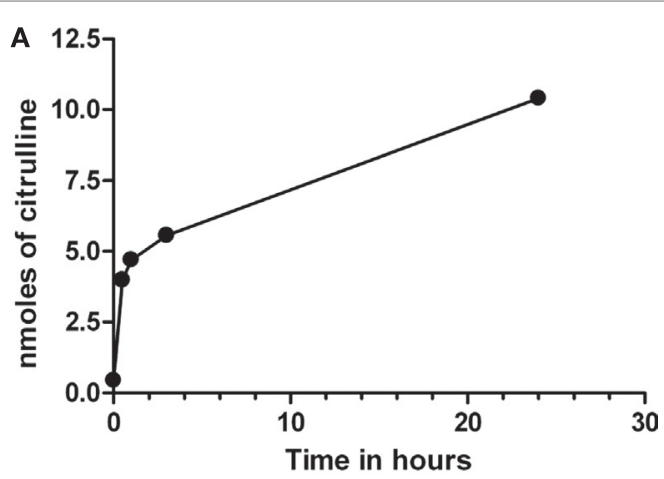

B

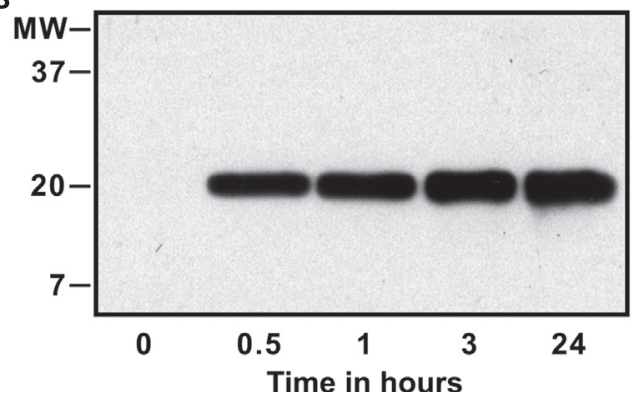

FIGURE 1 | In vitro deimination of histones by peptidylarginine deiminase (PAD) 4. Calf-thymus histones $(0.1 \mathrm{mM})$ were incubated with $0.2 \mu \mathrm{M}$ of recombinant PAD4 for up to $24 \mathrm{~h}$, and nanomoles of citrulline produced were determined by colorimetry at $595 \mathrm{~nm}$ using citrulline standard solution (A). Calf-thymus histones from time points tested above were probed on Western blot with a commercial antibody that reacts against the amino terminus of histone $\mathrm{H} 3$ with citrullines at positions 2, 8, and 17 (Abcam, ab\#5103). Deimination was detected at each time point except at time $=0$ and increased from 0.5 to $24 \mathrm{~h}$ (B). The reaction reached a plateau by $24 \mathrm{~h}$, and we calculated that 1.3 citrullines were present, on average, per histone $\mathrm{H} 3$ molecule.

$0.05 \%$ Tween-20 in PBS and blocked with $2.5 \%$ BSA in $0.02 \%$ $\mathrm{NaN}_{3}$ and PBS for $2 \mathrm{~h}$. A 1:100 initial dilution of primary sera along with threefold serial dilutions in $1.6 \%$ Tween-20 and $1 \%$ BSA in PBS were incubated for $1 \mathrm{~h}$ in the plates. Then, serum dilutions were removed, and wells were washed with $0.1 \%$ Tween-20 in PBS. Alkaline phosphate-conjugated goat anti-mouse kappa (Southern Biotech) was added at 1:1,000 dilution in 1\% BSA with 0.05\% Tween-20 in PBS for $1 \mathrm{~h}$. Phosphatase substrate (Sigma) was used to develop the ELISA, and OD values were read at $405 \mathrm{~nm}$ on a Multiscan Plus plate reader (Labsystems).

Serum antibodies against dsDNA were detected by ELISA exactly as described $(26,27)$. In short, calf-thymus dsDNA $(10 \mu \mathrm{g} / \mathrm{ml}$ in PBS) was coated on microtiter plates (MaxiSorb; Nunc, Copenhagen, Denmark). Sera from mice were diluted twofold from 1:100 to 1:3,200 in PBS containing 0.02\% Tween20 and incubated in wells. ELISA readings were obtained with peroxidase-conjugated rabbit anti-mouse $\mathrm{Fc}-\gamma$ antibodies at $405 \mathrm{~nm}$.

\section{Ex Vivo Tissue Lysate Preparation}

Seven-month-old B6.TC autoimmune female mice and age-matched control $\mathrm{B} 6 \mathrm{IgH}^{\mathrm{a}}$ were dissected to recover a portion of spleen, bone marrow, kidney, and liver. Thymi from
4- to 6-month-old mice were similarly obtained. Tissue was cut, minced with scissors, and crushed between two sterile frosted glass slides. Dissociated tissues were washed in PBS (without $\mathrm{Ca}^{++}$) and centrifuged at $5,000 \times g$ for 5 min to pellet cells. Cell pellets were mixed with lysis buffer (65mM Tris $\mathrm{pH} 7.2,2 \%$ SDS, $10 \%$ glycerol), containing protease inhibitors. To test for $\mathrm{dH}$ in tissue lysates, equal amounts of total protein were analyzed by Western blotting, as described below.

\section{Western Blot}

For Western blot analysis, proteins were resolved on $15 \%$ SDS-PAGE and transferred to nitrocellulose. Membranes were blocked in 5\% BSA in $0.1 \%$ Tween-20 in TBS (TBST) overnight at $4^{\circ} \mathrm{C}$. Subsequently, the membranes were incubated with sera at 1:500 dilution in TBS containing 2.5\% BSA, $1 \%$ NP-40, and $0.1 \%$ SDS. After $2 \mathrm{~h}$ of incubation, membranes were washed with $1 \%$ NP-40 in TBS. Anti-mouse IgG-HRP was used for detection at 1:20,000 dilution in TBST for $1 \mathrm{~h}$, and blots were developed using chemiluminescence (PerkinElmer).

Peptide inhibition assays included a preceding step, in which $3 \mu \mathrm{g}$ of 20 -mer peptides, both matching the amino terminus of $\mathrm{H} 3$ but either containing arginines or citrullines at positions 2, 8, and 17, were incubated with 1:300 dilutions of mouse sera for $1 \mathrm{~h}$ prior to use in binding to $\mathrm{dH}$ and $\mathrm{nH}$ on the membrane. Results of these Western blots were quantitated by infrared emission of secondary anti-mouse IgG antibodies (Odyssey). Separately, autoimmune sera were treated with DNase1 prior to Western blotting. Briefly, $400 \mu \mathrm{l}$ of a 1:200 dilution of sera were incubated with 20 units of DNase1 (New England Biolabs) for $1 \mathrm{~h}$ at room temperature to limit the possibility that DNA-anti-DNA complexes present in sera contribute to the observed histone binding. Following this incubation, the sera were diluted 1:500 in Western blot binding buffer.

To probe for deiminated histone $\mathrm{H} 3(\mathrm{dH} 3)$ in B6.TC and B6 mice, equal amounts of tissue lysates were resolved on 12\% SDSPAGE and transferred to nitrocellulose. Membranes were blocked with 5\% BSA in TBST for $30 \mathrm{~min}$ and incubated with anti-dH3 anti-citrullinated histone $\mathrm{H} 3$ rabbit antibodies (Abcam, ab\#5103) overnight at $4^{\circ} \mathrm{C}$. Membranes were washed and incubated with HRP-conjugated goat-anti-rabbit secondary IgG antibody for $1 \mathrm{~h}$ at room temperature, washed three times in TBST, and twice in TBS alone. The HRP activity was detected as above.

\section{Splenocyte Proliferation Assay}

$\mathrm{BALB} / \mathrm{c}$ mice were boosted twice with $100 \mu \mathrm{g}$ of total histones ( $\mathrm{dH}$ or $\mathrm{nH}$ ) or $100 \mu \mathrm{g}$ OVA, 14 and 2 days prior to the splenocyte proliferation assay. Ninety-six well tissue culture plates (Corning Incorporated) were filled with $100 \mu \mathrm{l}$ aliquots of $100 \mu \mathrm{g} / \mathrm{ml}$ (or threefold serial dilutions) of $\mathrm{dH}, \mathrm{nH}$, or OVA in RPMI 1640 (Mediatech Inc.) supplemented with 10\% FBS. Splenocytes were isolated and resuspended in RPMI with $10 \%$ FBS at $1 \times 10^{6}$ cells $/ \mathrm{ml}$. One hundred microliters of cell suspension was added to each well, and plates were incubated at $37^{\circ} \mathrm{C}$ in $5 \% \mathrm{CO}_{2}$ for 72 to $96 \mathrm{~h}$. Tritiated thymidine $(1 \mu \mathrm{Ci} /$ well $)$ was added for the last $17 \mathrm{~h}$ of incubation. Plates were harvested onto glass fiber filters, and thymidine incorporation was assessed by scintillation counting. Splenocyte proliferation assays were also performed using 
female NZB/W mice purchased from the Jackson Laboratory (Bar Harbor, ME, USA). Splenocytes were collected from NZB/W mice of different ages. Following red blood cell lysis, the splenocytes were resuspended in DMEM-10 media with 10\% FCS and $10,000 \mathrm{U} / \mathrm{ml}$ penicillin and $10 \mathrm{mg} / \mathrm{ml}$ streptomycin. One hundred thousand cells were incubated with $\mathrm{dH}$ or $\mathrm{nH}(20 \mu \mathrm{g} / \mathrm{ml}$ of protein) in triplicate wells. Tritiated thymidine incorporation $(1 \mu \mathrm{Ci} /$ well) was measured after 20 h, 3 or 6 days by liquid scintillation, as described $(28,29)$.

\section{RESULTS}

\section{Spontaneously Arising Anti-Histone Autoantibodies}

To assess the production of anti- $\mathrm{nH} / \mathrm{dH}$ autoantibodies in mice that spontaneously develop antinuclear autoantibodies, we tested sera from $\mathrm{NZB} / \mathrm{W}$ and their recombinant inbred derivative strain NZM2410 for binding to $\mathrm{nH}$ and $\mathrm{dH}$. In addition, we tested the contribution of lupus-predisposing genetic intervals Sle1 and Sle3 that were back-crossed from the NZM2410 onto the B6 background (B6.Sle1 and B6.Sle1. Sle3). Sle 1 is a locus that breaks tolerance to chromatin, whereas Sle 3 affects functions of myeloid cells (30). The parental strains, NZB and NZW, have distinct MHC, H-2 ${ }^{\mathrm{d}}$ and $\mathrm{H}-2^{z}$, respectively. The lupus-predisposing $\mathrm{H}-2^{\mathrm{z}}$ was maintained in the NZM2410 congenics, whereas the Sle1 and Sle 3 congenics have the $\mathrm{H}-2^{\text {b }}$ from $\mathrm{B} 6$. Antibody binding to $\mathrm{dH}$ and $\mathrm{nH}$ was assessed by ELISA (Figure 2) and Western blot (Figure 3). As controls, sera from age- and sex-matched B6 mice were used.

By ELISA, NZB/W (Figure 2A), B6.Sle1 (Figure 2B), B6.Sle1. Sle3 (Figure 2C), and NZM2410 (Figure 2D) sera showed preference for $\mathrm{nH}$ over $\mathrm{dH}$. This preferential binding was statistically significant for NZB/W, NZM2410, and B6.Sle1.Sle3, as assessed by paired, one-tailed $T$-test. Binding differed for different mice and dilutions but, in general, binding to $\mathrm{nH}$ was stronger than the binding to $\mathrm{dH}$. We also confirmed the additive effect of Sle1 and Sle3 loci, as the B6.Sle1.Sle3 combination resulted in greater absorbance values relative to the B6.Sle1 mice. In parallel assays, sera from B6 mice (Figure 2E) showed no reactivity to histones. Both $\mathrm{dH}$ and $\mathrm{nH}$ were present in equivalent concentrations on the plates, as shown by the nearly identical binding of the LG2.2 monoclonal antibody (Figure 2F) whose epitope, the first 13 amino acid residues of histone $\mathrm{H} 2 \mathrm{~B}$, is identical between $\mathrm{nH}$ and $\mathrm{dH}(31)$.

To examine the possibility that antibodies to $\mathrm{dH}$ arise first but are replaced by antibodies to $\mathrm{nH}$, we collected mouse sera over time to identify mice during the conversion to anti-histone autoimmunity. In Figure 2G, we show that binding preference to $\mathrm{nH}$ over $\mathrm{dH}$ was present at an early time when anti-histone reactivity first appeared. This result indicates the two reactivities arise jointly, rather than in succession, as might be predicted by epitope spreading.

To dissect the preferential binding to $\mathrm{nH}$, we used Western blotting. The stringency of binding was increased by including both SDS (0.05\%) and NP-40 (0.5\%) in the binding buffer.
Indeed, under these conditions, the binding of serum antibodies from NZB/W, NZM2410 B6.Sle1, and B6.Sle1.Sle3 mice to $\mathrm{dH}$ was weaker relative to the binding to $\mathrm{nH}$, such that many of the sera bound exclusively to $\mathrm{nH}$ (Figure $\mathbf{3 A}$ ). A variety of binding patterns were observed, including exclusive binding to one or two core histones. Binding to $\mathrm{dH} 3$ was observed most often, whereas binding to deiminated $\mathrm{H} 4$ or $\mathrm{H} 2 \mathrm{~A}$ was rare. In addition, binding to a band with the mobility of the deiminated linker histone $\mathrm{H} 1$ was observed in several blots. Overall, binding was more biased toward $\mathrm{nH}$ over $\mathrm{dH}$, although some IgG dH was also observed in individual NZM2410 and B6.Sle1.Sle3 mice. In no instance did binding to $\mathrm{nH}$ exceed binding to $\mathrm{dH}$.

To examine the possibility that the binding to $\mathrm{dH}$ represented a truly separate population of antibodies, we conducted inhibition experiments using 20-mer peptides that matched the amino terminus of histone $\mathrm{H} 3$ and either contained arginines or citrullines at positions 2, 8, and 17 (Figure 3B). We observed that the arginine-containing peptide (orange bars) was a more effective inhibitor of binding to both $\mathrm{nH}$ and $\mathrm{dH}$, relative to the citrullinecontaining peptide (blue bars), suggesting that the antibody binding to either antigen reflects antibody specificity for $\mathrm{nH}$ and that the binding to $\mathrm{dH}$ likely represents cross-reactivity due to shared epitope structure.

\section{Splenocyte Proliferation}

We asked whether $\mathrm{T}$ cells from autoimmune mice also recognize $\mathrm{dH}$ by using NZB/W mice that spontaneously develop an autoimmune response against nuclear Ags, including DNA and histones (32). Splenocytes from NZB/W mice of different ages were tested for proliferation in the presence of $\mathrm{dH}$ or $\mathrm{nH}$. At 6-10 weeks of age, prior to any measurable anti-DNA reactivity, the splenocytes did not proliferate in response to either form of histone (Figures 4A,B). At 20-21 weeks of age, anti-DNA autoantibodies could be detected in the sera of some NZB/W mice (indicated at the top of each panel), and splenocytes from these mice showed low levels of proliferation in response to $\mathrm{nH}$ and $\mathrm{dH}$ (Figures 4C,D). Thus, splenocyte responses to histones arose in parallel with, or slightly prior to, humoral responses to DNA.

Twenty-five-week-old NZB/W mice with established autoimmunity showed splenocyte proliferation in response to $\mathrm{dH}$ and $\mathrm{nH}$ (Figures 4E,F), suggesting the presence of histone-reactive $\mathrm{T}$ cells in the spleens of autoimmune mice. Although some mice showed a tendency to preferentially respond to $\mathrm{dH}$, others preferred $\mathrm{nH}$, as shown by data from two of the analyzed mice. Notably, preference could switch, depending on the length of stimulation (Figures $4 \mathrm{E}, \mathrm{F}$ ), suggesting the presence of a limited number of $\mathrm{T}$ cell clones with distinct specificities and growth characteristics. Because proliferation generally showed a bias for $\mathrm{dH}$ or $\mathrm{nH}$ rather than being equal, we infer that epitopes containing arginines or citrullines were both presented by the MHC and recognized by $\mathrm{T}$ cells in splenocytes.

To examine the ability of $\mathrm{dH}$ to drive a $\mathrm{T}$ cell response, we examined $\mathrm{T}$ cell proliferation in vitro. Splenocytes from BALB/c mice immunized with $\mathrm{dH}$ proliferated during incubation with dH (Figure 4G) to comparable extent as splenocytes from mice 

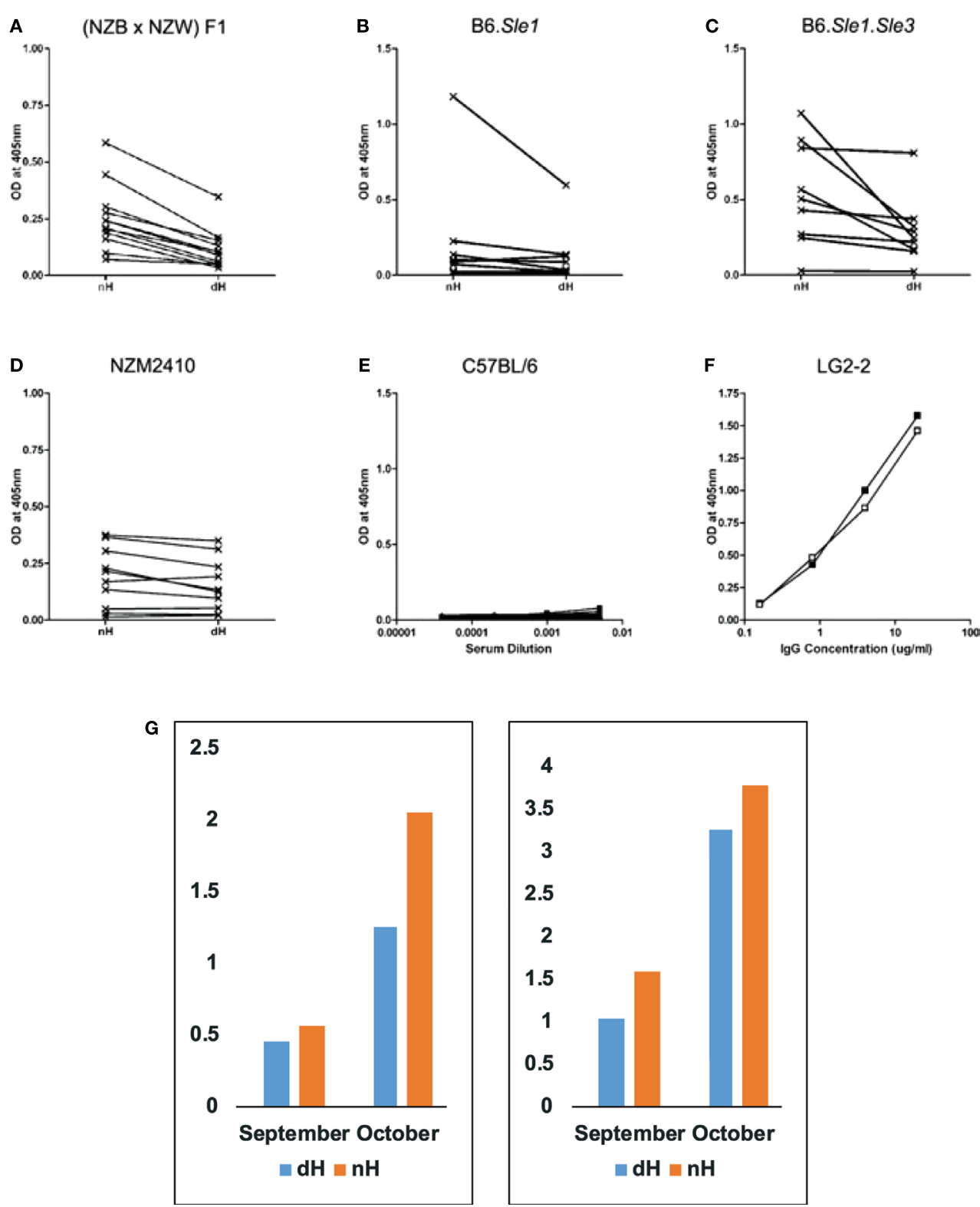

FIGURE 2 | Binding of IgG from autoimmune-prone and control mice to non-deiminated histones (nH) and deiminated histones (dH). Sera from NZB/W (A), B6.Sle1 (B), B6.Sle1.Sle3 (C), NZM2410 (D), and control B6 (E) mice were tested for lgG binding to $\mathrm{nH}$ and dH. Complete binding curves were obtained, and OD values for a single dilution were plotted in panels (A-D). We plotted data from 1:1,000 dilutions in panels (A-C) and from the 1:200 dilution in panel (D). Absorbance values for each serum corresponding to $\mathrm{lgG}$ binding to $\mathrm{dH}$ and $\mathrm{nH}$ are shown and are connected by a line indicating the pairs of data for the binding of each serum to the two antigens. Significance of the readings was tested by paired, one-tailed $T$-test. Binding to $\mathrm{dH}$ was significantly less than to $\mathrm{nH}$ for $\mathrm{NZB} / \mathrm{W}$ ( $p<0.0001)$, NZM2410 ( $p<0.016)$, and B6.Sle1.Sle3 $(p<0.016)$. The binding of B6.Sle1 lgG tended to be lower to dH ( $p<0.10)$. IgG from mice with systemic lupus erythematosus susceptibility genes showed preferential binding to $\mathrm{nH}$. In comparison, control B6 mice showed negligible binding to either form of histones (E). As control for equal coating of Ags, we used LG2-2, a mouse anti-histone H2B mAb (F), whose epitope does not include any residues that are substrates for deimination (31). Thus, the binding curves for $\mathrm{dH}$ (filled symbols) and $\mathrm{nH}$ (open symbols) are nearly superimposable. Individual mice were followed over time (G), to observe the initial development of anti-histone autoreactivity. Two NZB/W mice that first showed anti-histone reactivity at 4 months of age (September) reacted more strongly to $\mathrm{nH}$ than to $\mathrm{dH}$, and the preferential antibody binding was maintained at 5 months of age (October). The sera were diluted $1: 300$, and the measurements were performed three times with consistent results. The Y-axis displays values of optical density measured by ELISA.

immunized with OVA and incubated with OVA (Figure 4I). By contrast, splenocytes from BALB/c mice immunized with $\mathrm{nH}$ showed no enhanced proliferation regardless of whether they were incubated with $\mathrm{dH}, \mathrm{nH}$, or media alone (Figure $4 \mathbf{H}$ ).

\section{Spleens of Autoimmune Mice Have Increased Levels of $\mathbf{d H}$}

To test for the presence of $\mathrm{dH}$ in vivo, we prepared tissue lysates of bone marrow, spleen, liver, kidney, and thymus from B6.TC 


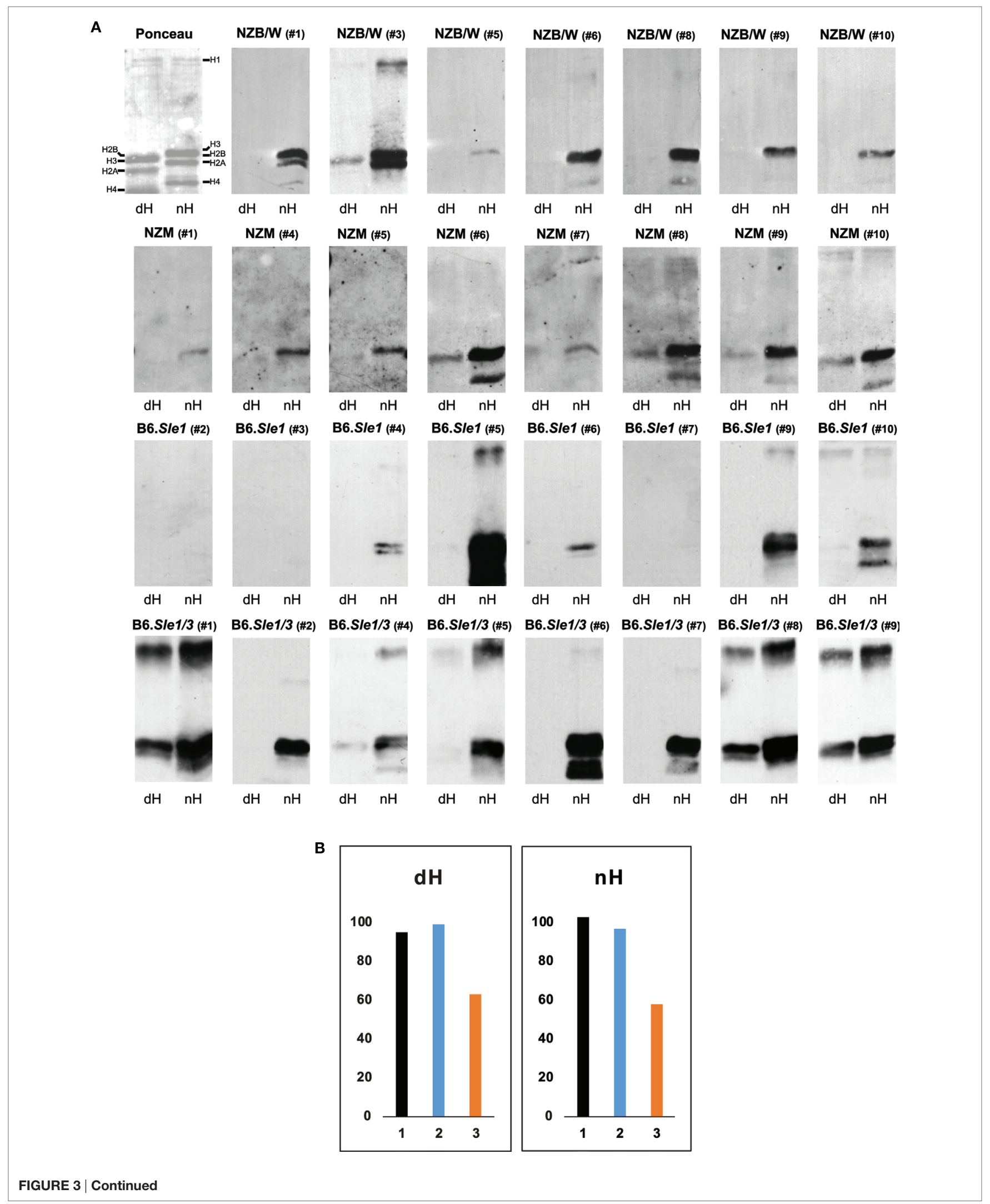




\section{FIGURE 3 | Continued}

Western blot of IgG to deiminated histones $(\mathbf{d H})$ and non-deiminated histones $(\mathbf{n H})$. Equal amounts of $\mathrm{dH}$ and $\mathrm{nH}$ were resolved on SDS-PAGE, transferred to nitrocellulose, and stained with Ponceau red (upper left panel). The stained bands migrating with the mobilities of core and linker histones are indicated along the margins. Note that due to the replacement of the positively charged arginine by the neutral citrulline, the electrophoretic mobility of certain core histones is increased in the $\mathrm{dH}$ sample, indicating nearly complete modification by peptidylarginine deiminase 4. (A) Strips of membrane containing $\mathrm{nH}$ or $\mathrm{dH}$ were probed with $\mathrm{NZB}$ W, NZM2410, B6.Sle1, and B6.Sle1.Sle3 sera at 1:500 dilution and developed with anti-mouse IgG-horseradish peroxidase. Autoimmune-prone mouse sera bound nH in preference to $\mathrm{dH}$. The experiments were performed at least three times with consistent results. (B) To explore whether the binding to histones on the membranes is equally sensitive to inhibition by 20 -mer peptides matching the $\mathrm{H} 3$ amino terminus and containing arginine residues (nH peptide; orange bars) versus citrulline residues ( $\mathrm{dH}$ peptide; blue bars) at positions 2, 8, and 17, we preincubated an NZB/W serum that showed binding to both $\mathrm{nH}$ and $\mathrm{dH}$ (black bars) with either peptide, as described in Section "Materials and Methods," and carried out the Western blots. The nH peptide was a more effective inhibitor of binding to both histones than the $\mathrm{dH}$ peptide. The $Y$-axis indicates binding intensities in units of infrared emission (IE).
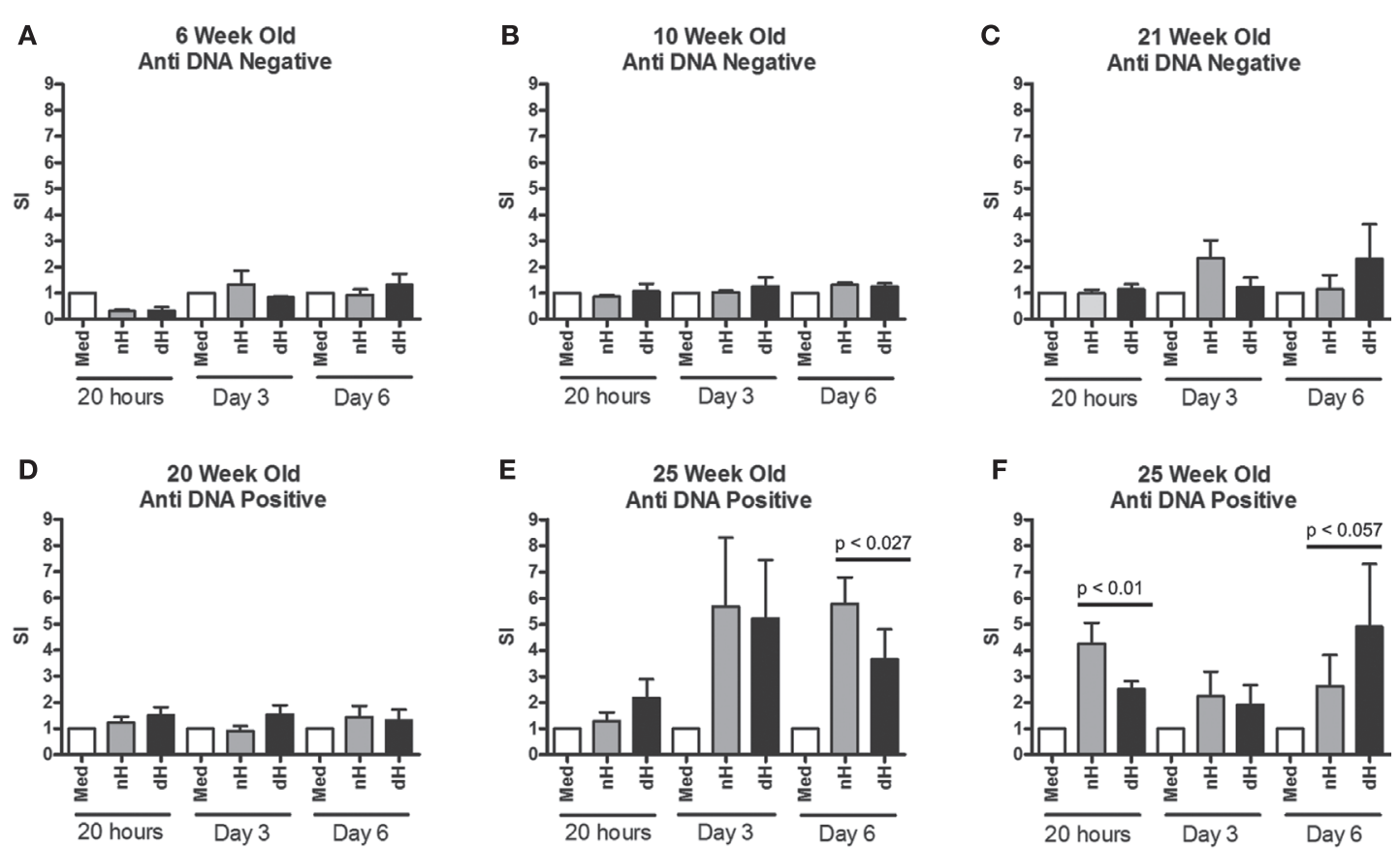

G dH Immunized

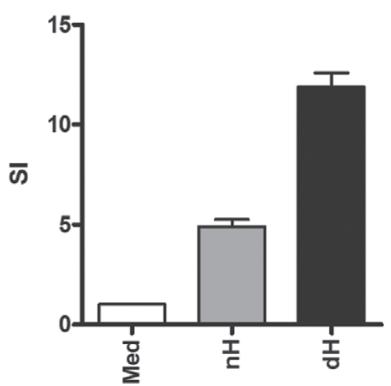

H

nH Immunized

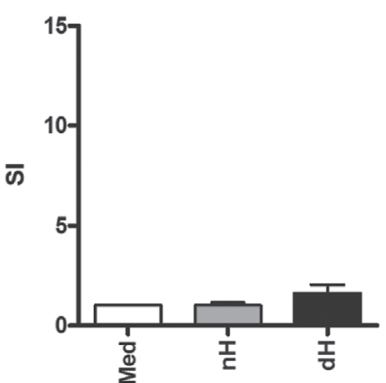

\section{Ova Immunized}

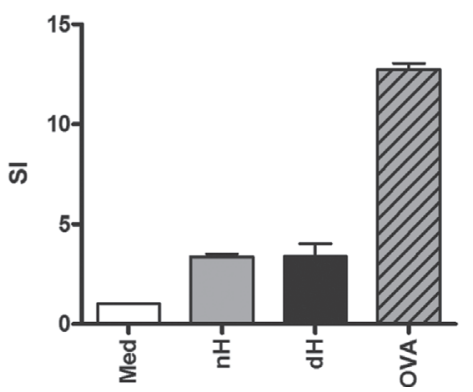

FIGURE 4 | Proliferation of splenocytes from NZB/W and immunized BALB/c mice. Splenocytes derived from NZB/W mice of different ages were tested for dsDNA binding by ELISA (A-F). In parallel, splenocytes were stimulated with deiminated histones (dH) or non-deiminated histones (nH) in vitro, as indicated. Proliferation was assessed following 4 h, 3 and 6 days in culture, and the response was determined by [ $\left.{ }^{3} \mathrm{H}\right]$ thymidine incorporation. In addition, splenocytes from mice immunized with $\mathrm{dH}(\mathbf{G})$ or $\mathrm{nH}(\mathbf{H})$ were tested for proliferation in response to $\mathrm{dH}$ or $\mathrm{nH}$, or ovalbumin (I) as control. The results are presented as stimulation indices (SI) that were calculated from mean cpm values of triplicate wells. The significance of differences between samples was determined by unpaired $T$-test, and the $p$ values are indicated.

mice and probed them with anti-dH by Western blot. The bone marrow lysates of autoimmune B6.TC mice and control mice at 7 months of age did not appreciably react with antibodies to
dH3 (Figure 5A). By contrast, spleens of B6.TC mice had clearly increased levels of $\mathrm{dH} 3$ as compared to $\mathrm{B} 6$ controls or lysates of the Jurkat lymphoma cells (Figure 5B). These results provide a 

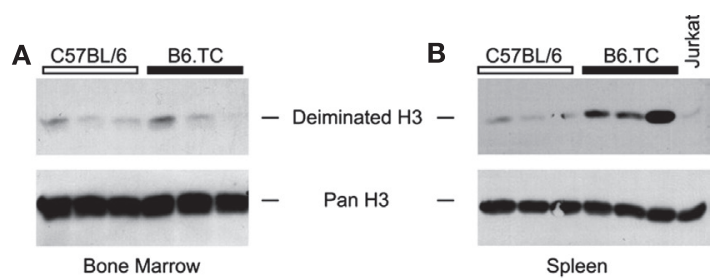

C
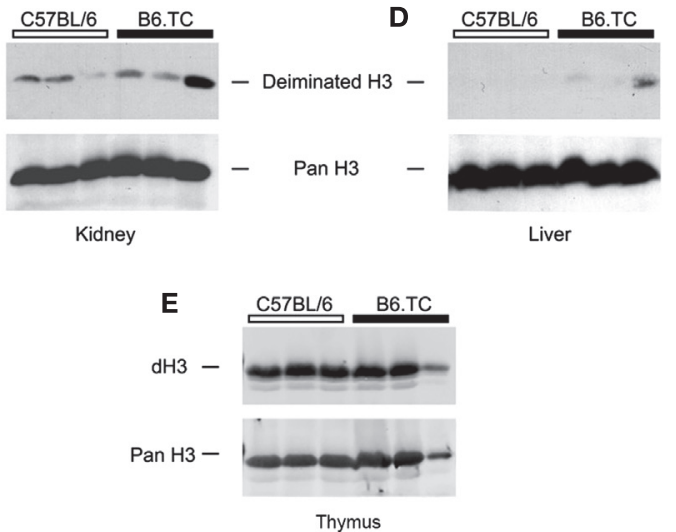

FIGURE 5 | Western blot detection of deiminated histone $\mathrm{H3}$ (dH3) in mouse tissues. Equal amounts of freshly prepared lysates from bone marrow (A), spleen (B), kidney (C), liver (D), and thymus (E) of autoimmune B6.TC and control B6 mice were blotted onto nitrocellulose membranes and probed with anti-dH3 antibody. Tissues from three mice were tested in each group. As control, Jurkat lymphoma cells were used (B). The same blots were also re-probed with an antibody that recognizes total histone H3 (Pan $\mathrm{H} 3$ ) to confirm equal loading of lysates.

qualitative estimate rather than a precise measure of deimination. This is by necessity, as the cellular composition and disease process may affect histone deimination in a complex manner in a tissue such as the spleen. The overall amounts of histone H3 were similar in all samples, as indicated by the equivalent immunoreactivity of an anti-H3 antibody. Therefore, the spleens of autoimmune B6.TC mice contained increased quantities of $\mathrm{dH} 3$. In addition, the kidneys and the liver from individual autoimmune mice exhibited increased levels of $\mathrm{dH} 3$ (Figures 5C,D). Importantly, thymic extracts from 4- to 6-month-old B6 and B6.TC mice clearly showed constitutively elevated levels of $\mathrm{dH}$ (Figure 5E).

\section{DISCUSSION}

In this study, we observed that autoimmune mice exhibit a striking $\mathrm{B}$ cell bias toward binding $\mathrm{nH}$ over $\mathrm{dH}$, a bias that is present at the earliest stages of anti-histone autoimmunity (Figure 2G). In 28 of 28 autoimmune NZB/W, NZM2410, B6.Sle1, and B6.Sle1. Sle3 mice that made IgG anti-histone antibodies, preference was invariably in favor of $\mathrm{nH}$ (Figure 3A). Even more strikingly, in 18 animals that produced antibodies to $\mathrm{nH}$, immunoblotting could not detect antibodies to $\mathrm{dH}$. To exclude the possibility that anti$\mathrm{dH}$ antibodies are only transiently expressed, or ensconced in immune complexes, we carried out longitudinal antibody-binding assays that consistently revealed preferential or exclusive binding to $\mathrm{nH}$ (Figure 2G). These results indicate that, even in mouse strains that spontaneously convert to autoimmunity, deimination reduces IgG binding to histones, and autoantibody binding is focused on arginine-containing epitopes that are absent from $\mathrm{dH}$. It follows that $\mathrm{dH}$ remain effective tolerogens even after development of autoimmunity in the tested mouse strains. We conclude this is an important characteristic of autoimmune mice, and we propose that a more detailed comparison with autoimmune disease patients may shed light on the induction of autoimmunity. Moreover, we argue that the specific regulation of PAD4 underlies these results.

Peptidylarginine deiminase 4 is most abundant in granulocytes and other cells of the innate immune system. However, PAD4 is also expressed in another immunologically relevant context. In elegant studies, Ireland and Unanue described the fact that antigen-presenting cells in mice express PAD4 and PAD2 in a compartment that is regulated by proteins in the autophagy pathway (33). The deiminase activity is constitutively expressed in dendritic cells and macrophages, whereas it is inducible in B cells by stress or stimulation through the Ig antigen receptor (33). The authors reported that arginine residues in antigenic peptides are converted to citrullines, and that $\mathrm{T}$ cells respond to target antigenic epitopes containing citrulline. This mechanism was demonstrated by using foreign antigens, in their case, hen egg lysozyme that was administered in a conventional immunization. The resulting $\mathrm{T}$ cell clones bound preferentially, or even exclusively citrullinated lysozyme peptides. Our results support this mechanism because splenocytes from $\mathrm{BALB} / \mathrm{c}$ mice proliferated as vigorously against $\mathrm{dH}$ as against OVA (Figure 4G versus Figure 4I). By contrast, splenocytes from NZB/W mice, after these mice had converted to autoimmunity, showed comparable proliferation to either antigen (Figures $4 \mathrm{E}, \mathrm{F}$ ). This fundamental difference in outcome points to differences in immunized versus spontaneous autoimmune responses to $\mathrm{nH}$.

As further shown by Ireland and Unanue, autophagy induction in B cells is necessary for their inducible expression of PAD4 activity associated with antigen processing (33). Conversely, a transient or sustained impairment of autophagy in B cells could provide conditions that would support the presentation of histone epitopes lacking citrullines. Under these conditions, B cells would express peptide epitopes that could act as neo-antigens for T cells and solicit T cell help. Autophagy has been linked by genetics to autoimmunity (27). A contribution of the autophagic processes to autoimmunity is consistent with the deficient or impaired functions of ATG5 (and other components of non-canonical autophagy) in SLE, but the mechanism for this relationship is unclear $(27,28)$. Our data suggest that effective autophagy may be required to maintain certain aspects of immune tolerance in mice.

However, an unanswered question is whether deiminated peptide presentation also occurs during thymic development, and whether tolerizing peptides expressed by thymic antigenpresenting cells are also deiminated. In support of this possibility, we found that thymus lysates from B6 and B6.TC mice show abundant histone deimination (Figure 5E), a result that suggests antigen presentation in the mouse thymus is tightly linked to 
deimination. If so, citrulline-containing epitopes of autoantigens such as histones may induce powerful tolerance in mice. In that scenario, only B cells that bound to $\mathrm{nH}$ and presented nondeiminated epitopes would break tolerance and receive T cell help. Consequently, autoimmunity might initially be directed against non-deiminated peptides, provided that B cells, at an early stage of autoimmune pathogenesis, suspend or shut off the deimination of processed epitopes. Support for this alternative comes from the consistent anti-nH response that we observed in numerous autoimmune mice from different autoimmune strains (Figures 1 and 2). Thus, only B cells that no longer expressed PAD4 activity in their antigen processing compartment may escape tolerance. Our hypothesis of the key dependence of self-tolerance on the adequate function of autophagy for the presentation of $\mathrm{dH}$ peptides is in line with the remarkable preference of autoimmune mouse antibodies for $\mathrm{nH}$. As corollary, a steady-state balance between $\mathrm{nH}$ and $\mathrm{dH}$ may be maintained under pre-autoimmune conditions, but an imbalance between the supply, processing, or recognition of $\mathrm{nH}$, likely coincident with a disturbance of autophagic antigen processing in B cells, may result in an antigenspecific response to $\mathrm{nH}$ that may break immune tolerance and result in a sustained autoimmune response to $\mathrm{nH}$.

To conclude, we briefly address the difference between mice and humans in their ability to express antibodies to $\mathrm{dH}$. As we and others have shown, autoantibodies in various human autoimmune conditions preferentially bind $\mathrm{dH}(3,24,34)$, in striking contrast with the opposite bias in mice. Again, the key may be in the expression of PAD4 activity in B cells. Our tissue expression results indicate the increased presence of $\mathrm{dH}$ in the spleens of autoimmune mice (Figure 5B). By contrast, healthy human B cells appear incapable of expressing PAD4, as indicated by data

\section{REFERENCES}

1. Aletaha D, Neogi T, Silman AJ, Funovits J, Felson DT, Bingham CO III, et al. 2010 rheumatoid arthritis classification criteria: an American College of Rheumatology/European League Against Rheumatism collaborative initiative. Ann Rheum Dis (2010) 69(9):1580-8. doi:10.1136/ard.2010. 138461

2. Dwivedi N, Upadhyay J, Neeli I, Khan S, Pattanaik D, Myers L, et al. Felty's syndrome autoantibodies bind to deiminated histones and neutrophil extracellular traps. Arthritis Rheum (2012) 64(4):982-92. doi:10.1002/art.33432

3. Dwivedi N, Neeli I, Schall N, Wan H, Desiderio DM, Csernok E, et al. Deimination of linker histones links neutrophil extracellular trap release with autoantibodies in systemic autoimmunity. FASEB J (2014) 28(7):2840-51. doi:10.1096/fj.13-247254

4. Vossenaar ER, Zendman AJ, van Venrooij WJ, Pruijn GJ. PAD, a growing family of citrullinating enzymes: genes, features and involvement in disease. Bioessays (2003) 25(11):1106-18. doi:10.1002/bies.10357

5. Neeli I, Khan SN, Radic M. Histone deimination as a response to inflammatory stimuli in neutrophils. J Immunol (2008) 180(3):1895-902. doi:10.4049/ jimmunol.180.3.1895

6. Chang HH, Dwivedi N, Nicholas AP, Ho IC. The W620 polymorphism in PTPN22 disrupts its interaction with peptidylarginine deiminase type 4 and enhances citrullination and NETosis. Arthritis Rheumatol (2015) 67(9):232334. doi:10.1002/art.39215

7. Muller S, Radic M. Citrullinated autoantigens: from diagnostic markers to pathogenetic mechanisms. Clin Rev Allergy Immunol (2015) 49(2):232-9. doi:10.1007/s12016-014-8459-2

8. Dwivedi N, Radic M. Citrullination of autoantigens implicates NETosis in the induction of autoimmunity. Ann Rheum Dis (2014) 73(3):483-91. doi:10.1136/ annrheumdis-2013-203844 in the Human Protein Atlas (35). There, evidence suggests that human B cells, even after B cell antigen engagement in the white pulp, fail to express detectable PAD4. Thus, expression of $\mathrm{dH}$ epitopes on human B cells may not be intrinsic to the B cells, and presentation of $\mathrm{dH}$ epitopes may not engender tolerance that it is as effective as it is in mice. Consequently, B cell presentation of deiminated peptides in humans may be more likely to break tolerance and lead to ACPA generation.

\section{AUTHOR CONTRIBUTIONS}

All authors were involved in drafting the article or revising it critically for important intellectual content, and approved the final version to be published. MR had full access to all the data in the study and took responsibility for the integrity of the data and the accuracy of data analysis. Study conception and design: ND, MS, LM, OR, and MR. Acquisition of data: ND, AH, YZ, IN, and MR. Analysis and interpretation of data: ND, AH, YZ, IN, MS, $\mathrm{LM}, \mathrm{OR}$, and MR.

\section{ACKNOWLEDGMENTS}

The authors thank Drs. Bryan Knuckley and Paul Thompson for the generous gift of recombinant PAD4, Dr. Chandra Mohan for B6.Sle1 and B6.Sle1.Sle3 sera, Dr. Seung-Chul Choi for help with the dissection of mouse tissues, and Dr. Salar Khan for critical comments on the manuscript. They thank Tim Higgins, senior illustrator, for expert assistance in preparation of the figures. The studies were supported by the Lupus Research Institute of New York, NY, USA, the Dana Foundation Program in Human Immunology, and the ORR Fund to MR.

9. Khandpur R, Carmona-Rivera C, Vivekanandan-Giri A, Gizinski A, Yalavarthi S, Knight JS, et al. NETs are a source of citrullinated autoantigens and stimulate inflammatory responses in rheumatoid arthritis. Sci Transl Med (2013) 5(178):178ra40. doi:10.1126/scitranslmed.3005580

10. Spengler J, Lugonja B, Ytterberg AJ, Zubarev RA, Creese AJ, Pearson MJ, et al. Release of active peptidyl arginine deiminases by neutrophils can explain production of extracellular citrullinated autoantigens in rheumatoid arthritis synovial fluid. Arthritis Rheumatol (2015) 67(12):3135-45. doi:10.1002/ art.39313

11. Darrah E, Rosen A, Giles JT, Andrade F. Peptidylarginine deiminase 2, 3 and 4 have distinct specificities against cellular substrates: novel insights into autoantigen selection in rheumatoid arthritis. Ann Rheum Dis (2012) 71(1):92-8. doi:10.1136/ard.2011.151712

12. Romero V, Fert-Bober J, Nigrovic PA, Darrah E, Haque UJ, Lee DM, et al. Immune-mediated pore-forming pathways induce cellular hypercitrullination and generate citrullinated autoantigens in rheumatoid arthritis. Sci Transl Med (2013) 5(209):209ra150. doi:10.1126/scitranslmed.3006869

13. Brinkmann V, Reichard U, Goosmann C, Fauler B, Uhlemann Y, Weiss DS, et al. Neutrophil extracellular traps kill bacteria. Science (2004) 303(5663):1532-5. doi:10.1126/science.1092385

14. Brinkmann V, Zychlinsky A. Beneficial suicide: why neutrophils die to make NETs. Nat Rev Microbiol (2007) 5(8):577-82. doi:10.1038/nrmicro1710

15. Pratesi F, Panza F, Paolini I, Petrelli F, Puxeddu I, Casigliani-Rabl S, et al. Fingerprinting of anti-citrullinated protein antibodies (ACPA): specificity, isotypes and subclasses. Lupus (2015) 24(4-5):433-41. doi:10.1177/0961203314560005

16. Lande R, Ganguly D, Facchinetti V, Frasca L, Conrad C, Gregorio J, et al. Neutrophils activate plasmacytoid dendritic cells by releasing self-DNApeptide complexes in systemic lupus erythematosus. Sci Transl Med (2011) 3(73):73ra19. doi:10.1126/scitranslmed.3001180 
17. Garcia-Romo GS, Caielli S, Vega B, Connolly J, Allantaz F, Xu Z, et al. Netting neutrophils are major inducers of type I IFN production in pediatric systemic lupus erythematosus. Sci Transl Med (2011) 3(73):73ra20. doi:10.1126/ scitranslmed.3001201

18. van Bavel CC, Dieker J, Muller S, Briand JP, Monestier M, Berden JH, et al. Apoptosis-associated acetylation on histone $\mathrm{H} 2 \mathrm{~B}$ is an epitope for lupus autoantibodies. Mol Immunol (2009) 47(2-3):511-6. doi:10.1016/ j.molimm.2009.08.009

19. Liu CL, Tangsombatvisit S, Rosenberg JM, Mandelbaum G, Gillespie EC, Gozani OP, et al. Specific post-translational histone modifications of neutrophil extracellular traps as immunogens and potential targets of lupus autoantibodies. Arthritis Res Ther (2012) 14(1):R25. doi:10.1186/ $\operatorname{ar} 3707$

20. Seri Y, Shoda H, Suzuki A, Matsumoto I, Sumida T, Fujio K, et al. Peptidylarginine deiminase type 4 deficiency reduced arthritis severity in a glucose-6-phosphate isomerase-induced arthritis model. Sci Rep (2015) 5:13041. doi:10.1038/srep13041

21. Shelef MA, Sokolove J, Lahey LJ, Wagner CA, Sackmann EK, Warner TF, et al. Peptidylarginine deiminase 4 contributes to tumor necrosis factor alphainduced inflammatory arthritis. Arthritis Rheumatol (2014) 66(6):1482-91. doi:10.1002/art.38393

22. Konig MF, Darrah E, Andrade F. Insights into the significance of peptidylarginine deiminase 4 and antibodies against citrullinated antigens in the absence of "true ACPAs" in an experimental model of arthritis: comment on the article by Shelef et al. Arthritis Rheumatol (2014) 66(9):2642-4. doi:10.1002/ art.38719

23. Cantaert T, Teitsma C, Tak PP, Baeten D. Presence and role of anti-citrullinated protein antibodies in experimental arthritis models. Arthritis Rheum (2013) 65(4):939-48. doi:10.1002/art.37839

24. Pratesi F, Dioni I, Tommasi C, Alcaro MC, Paolini I, Barbetti F, et al. Antibodies from patients with rheumatoid arthritis target citrullinated histone 4 contained in neutrophils extracellular traps. Ann Rheum Dis (2014) 73(7):1414-22. doi:10.1136/annrheumdis-2012-202765

25. Kearney PL, Bhatia M, Jones NG, Yuan L, Glascock MC, Catchings KL, et al. Kinetic characterization of protein arginine deiminase 4: a transcriptional corepressor implicated in the onset and progression of rheumatoid arthritis. Biochemistry (2005) 44(31):10570-82. doi:10.1021/bi050292m

26. Moens U, Seternes OM, Hey AW, Silsand Y, Traavik T, Johansen B, et al. In vivo expression of a single viral DNA-binding protein generates systemic lupus erythematosus-related autoimmunity to double-stranded DNA and histones. Proc Natl Acad Sci U S A (1995) 92(26):12393-7. doi:10.1073/pnas.92.26.12393

27. Kalaaji M, Sturfelt G, Mjelle JE, Nossent H, Rekvig OP. Critical comparative analyses of anti-alpha-actinin and glomerulus-bound antibodies in human and murine lupus nephritis. Arthritis Rheum (2006) 54(3):914-26. doi:10.1002/art.21622
28. Andreassen K, Bredholt G, Moens U, Bendiksen S, Kauric G, Rekvig OP. T cell lines specific for polyomavirus $\mathrm{T}$-antigen recognize $\mathrm{T}$-antigen complexed with nucleosomes: a molecular basis for anti-DNA antibody production. Eur J Immunol (1999) 29(9):2715-28. doi:10.1002/(SICI)1521-4141(199909) 29:09<2715::AID-IMMU2715>3.3.CO;2-R

29. Bredholt G, Rekvig OP, Andreassen K, Moens U, Marion TN. Differences in the reactivity of CD4+ T-cell lines generated against free versus nucleosome-bound SV40 large T antigen. Scand J Immunol (2001) 53(4):372-80. doi:10.1046/j.1365-3083.2001.00873.x

30. Mehrad B, Park SJ, Akangire G, Standiford TJ, Wu T, Zhu J, et al. The lupus-susceptibility locus, Sle3, mediates enhanced resistance to bacterial infections. J Immunol (2006) 176(5):3233-9. doi:10.4049/jimmunol.176. 5.3233

31. Monestier M, Fasy TM, Losman MJ, Novick KE, Muller S. Structure and binding properties of monoclonal antibodies to core histones from autoimmune mice. Mol Immunol (1993) 30(12):1069-75. doi:10.1016/0161-5890(93) 90153-3

32. Lambert PH, Dixon FJ. Pathogenesis of the glomerulonephritis of NZB/W mice. J Exp Med (1968) 127(3):507-22. doi:10.1084/jem.127.3.507

33. Ireland JM, Unanue ER. Autophagy in antigen-presenting cells results in presentation of citrullinated peptides to CD4 T cells. J Exp Med (2011) 208(13):2625-32. doi:10.1084/jem.20110640

34. Dwivedi N, Upadhyay J, Neeli I, Khan S, Pattanaik D, Myers L, et al. Felty's syndrome autoantibodies bind to deiminated histones and neutrophil extracellular chromatin traps. Arthritis Rheum (2012) 64(4):982-92. doi:10.1002/ art. 33432

35. Uhlen M, Oksvold P, Fagerberg L, Lundberg E, Jonasson K, Forsberg M, et al. Towards a knowledge-based human protein atlas. Nat Biotechnol (2010) 28(12):1248-50. doi:10.1038/nbt1210-1248

Conflict of Interest Statement: The authors declare that the research was conducted in the absence of any commercial or financial relationships that could be construed as a potential conflict of interest.

The reviewers JD, EP, and GP and handling editor declared their shared affiliation, and the handling editor states that the process nevertheless met the standards of a fair and objective review.

Copyright (c) 2017 Dwivedi, Hedberg, Zheng, Neeli, Satoh, Morel, Rekvig and Radic. This is an open-access article distributed under the terms of the Creative Commons Attribution License (CC BY). The use, distribution or reproduction in other forums is permitted, provided the original author(s) or licensor are credited and that the original publication in this journal is cited, in accordance with accepted academic practice. No use, distribution or reproduction is permitted which does not comply with these terms. 